$\$$ Research Square

\title{
Coronavirus survey; a bibliometric analysis from 2012-2019.
}

\section{Akinyomade Owolabi}

Landmark University https://orcid.org/0000-0001-7626-836X

Joshua Opeyemi Folorunsho ( $\boldsymbol{\alpha}$ joshua.folorunsho@lmu.edu.ng )

Landmark University https://orcid.org/0000-0002-5571-6423

\section{Bolanle Akinsanola}

Landmark University

\section{Emmanuel Oludipe}

Landmark University

\section{Research Article}

Keywords: Coronavirus, Bibliometric, Scopus, MERS-CoV, SARS-CoV

Posted Date: April 9th, 2021

DOI: https://doi.org/10.21203/rs.3.rs-301025/v2

License: (c) (1) This work is licensed under a Creative Commons Attribution 4.0 International License. Read Full License 


\section{Abstract}

Background: Coronaviruses have emerged from animal reservoirs over the past decades to create severe illness and death. They are the SARS-CoV, MERS-CoV and more recently, the SARS-CoV2. This study is focused at assessing the characteristics of published works involving SARS-CoV and MERS-CoV at global level; using bibliometric analysis.

Methods: Peer-reviewed publications were retrieved from the Scopus database between 2012 and 2019. Data were analyzed in terms of the year, journal and number of publications, international collaboration patterns, research institutes, impact factor, h-index and number of times cited. Visual presentation and analysis of the data were performed using RStudio, Tableau and Microsoft Excel.

Results: A total of 1707 research publications were published across the world between 2012 and 2019 with the highest and lowest number of publications in 2016 (288) and 2012 (87). USA had 249 articles, followed by South Korea (186) and Saudi Arabia (111). The total number of citations achieved was 39,094 with Journal of Virology (133) had the highest number of published articles, followed by Emerging Infectious Disease (85) and PLOS One (60).

Conclusion: This research showed the international diversity of MERS-COV and SARS-CoV research with 106 countries. It is also not surprising that United States leads in the number of publications, authors and citations because of its global power and economic strength; this can also be said with the other top countries. Saudi Arabia was among the top rank because of the origination of the MERS-CoV in the middle east.

\section{Background}

Coronaviruses are a wide family of enveloped single-stranded RNA viruses that cause mild to severe illnesses in the upper-respiratory tract in mammals and birds; with a high mortality rate [1]. Mild illnesses are cases of common cold predominantly caused by Rhinoviruses, the severe cases cause SARS-CoV, MERS and SARS-CoV-2 [9,10,11]. Coronavirus was first identified by Dr. J. Almeida in 1964 at her laboratory in London St Thomas's Hospital [1,2]. The first severe outbreak of coronavirus (SARS-CoV) occurred in November, 2002 and ended July 31, 2003; infecting 8,096 humans in 29 countries and regions $[3,7]$. The second severe outbreak involved the MERS which was first discovered in September 2012 and has since spread to 27 countries with 2519 cases and 866 deaths $[4,7,12]$ the third and most recent/sever outbreak involved the COVID-19 that was discovered in December 2019 and has spread to 210 countries and regions with over 2.2 million cases and 150, 000 deaths as at April 17, 2020 [5]. Bibliometric tool-works have been largely used to explore the global contributions in several infectious diseases [8]. An up-to-date bibliometric research on SARS and MERS have not been reported in other to know the trends of coronavirus; the aim of this study is to perform an up-to-date global qualitative and quantitative bibliometric analysis of publications in Scopus to reveal the properties of global research output involving SARS-CoV and MERS-CoV before the discovery and outbreak of SARS-CoV-2. Findings 
from this study will provide a comprehensive view on coronaviruses before the discovery of the recent COVID-19 (SARS-CoV-2). This serves as an important reference for further studies including the research trends on the global pandemic COVID-19. Furthermore, it gives a broad view for editorial journals and authors on future research direction on coronaviruses.

\section{Methods}

Publications were retrieved from the Scopus database created and developed by Elsevier in the Netherlands $[13,14]$. Scopus contains a large database with more than 24,000 titles of which about 20,000 are peer-reviewed journals from about 5,000 international publishers $[14,15]$. It is known to harbor reliable data and can provide a larger information for analysis when compared to PubMed and Web of Science $[14,16]$. This study contains only English peer-reviewed research articles retrieved from 2012 till December 31, 2019 with specified search terms: "severe acute respiratory syndrome" or "middle east respiratory syndrome" or "MERS" or "SARS" or "coronavirus" or "SARS-CoV" as part of its title, abstract or keywords. Data involving the latest SARS-CoV outbreak (COVID-19) discovered in December 2019 were excluded from this bibliometric analysis. All of these terms are used in one query and retrieved in one day to avoid possible bias that comes from update on the Scopus database due to the constant change in metrics $[8,17,18]$. Data retrieved were analyzed quantitively and qualitatively by RStudio (1.2.5001), Tableau (2020.1) and Microsoft Excel (2019); involving the calculation of average, percentages, sum and relative frequencies [22]. Parameters analyzed include year of publications, patterns of international collaboration, country, journals author, keywords research institutions, $h$-index, impact factors (IF) and times cited [21, 22].

The measurement of the impact or productivity of the published researches in SARS-CoV, MERS-CoV, $h$ index and IF were used as indicators for this bibliometric evaluation. In 2005, Jorge E. Hirsch introduced the $h$-index as a metric that attempts to evaluate the citation and productivity impact of the publications of a region, scientist or scholar. The IF of the journals reported in the SCImago Journal \& Country Rank was used $[19,20]$. Ranking of the top journals was considered for this study and shown in descending order starting with the $1^{\text {st }}$ (standard competition ranking) as obtained from the day of retrieval.

\section{Results}

In this study, 1707 associated articles were retrieved, with 7444 authors and 39,094 citations at an average of 22.80 citations per documents (Table 1). The SARS-CoV and MERS-CoV associated articles originated from 106 countries/territories, indicating the global widespread of SARS-CoV and MERS-CoV research. A total number of $87(5.10 \%)$ articles were published in year 2012, $143(8.38 \%)$ in 2013, 243 (14.24\%) in 2014, 260 (15.23\%) in 2015, 288 (16.87\%) in 2016, 238 (13.94\%) in 2017, 223 (13.06\%) in 2018 and $225(13.18 \%)$ in 2019 (Figure 1), the annual growth of publications between the year 2012 and 2019 was recorded at $14.54 \%$. 
Table 2 shows the top countries/territories with the highest number of h-index publications including the number and percentage of their publications with international collaborations. Out of 1707 publications, United States had the highest number of contributors with 249 publications $(14.57 \%$ of total publications); this was followed by South Korea with 186 publications ( $10.89 \%$ of total publications), Saudi Arabia at 111 (6.50\%) publications and China (5.33\%). From the top ten countries with the most published articles, Netherlands had the highest publication percentage with international collaboration at $79.17 \%$ ( 19 out of its 24 articles); followed by Hong Kong at $56.09 \%$ ( 23 of its 41 articles) and Saudi Arabia at $54.05 \%$ (60 out of 111 articles) (Table 2). A network map was created using RStudio to visualize the network distribution and collaboration of countries/territories contributing to the field of MERS-COV and SARS-CoV research between 2012 and 2019, which is presented in Figure 2, matching the general ranking marks in Table 2.

This shows USA (86) with the highest number of articles with global collaboration, followed by Saudi Arabia (60), China (35), South Korea (27) and Germany (25).

The SARS-COV and MERS-CoV related articles were retrieved from 509 journals, but mostly in these journals: Journal of Virology (133), Emerging Infectious Disease (85), PLOS One (60) and Eurosurveillance (36); (Table 3). The impact factor (IF) for the top ten publication ranged from 2.48 (Journal of Infection and Public Health) to 9.58 (Proceedings of the National Academy of Science of the United States of America). Zaki et al. (1400) and Assiri et al. (587) produced the top 2 frequently cited publication; published in the New England Journal of Medicine with an impact factor of 70.67 (Table 4), this is followed by Agarwala et al. with 487 total citations in the Nucleic Acid Research journal (IF of 11.147) and Assiri et al. (391) in The Lancet Infectious Diseases (IF of 27.516).

The number of citations in this study was totaled at 39,094 (Table 5); with USA having the highest citations (7824), followed by Saudi Arabia (4701), Netherlands (3411), China (2294) and Germany (1951). Figure 3 shows the network map of the top 20 most productive institutions in SARS-CoV and MERS-CoV research created using RStudio between 2012 and 2019; with Ministry of Health, Saudi Arabia taking the lead as the most productive institute (84 publications), followed by Alfaisal University, Saudi Arabia (76), King Saud University, Saudi Arabia (63), The University of Hong Kong (62) and Centers for Disease Control and Prevention, USA (55).

From this study, 7444 authors were involved in the MERS-CoV and SARS-CoV research; Figure 4 shows the global map distribution (created using Tableau) of the top ten countries with the highest number of authors. USA recorded the highest number with 1763 authors, followed by Saudi Arabia (964), Hong Kong (767), China (715) and United Kingdom (322 authors).

\section{Discussion}

This bibliometric analysis of MERS-CoV and SARS-CoV examined global research trends between 2012 and 2019 based on data retrieved from Scopus database. Comparing previous studies on the SARS-CoV outbreak in 2003 , a rise in research followed by a decline may be due to the containment and near- 
eradication of the disease $[8,10,11,21,23]$. This trend may be seen in the novel coronavirus pandemic (COVID-19) after a decline in the disease spread due to vaccination or other safety precautions. In 2016 , WHO listed MERS-CoV and SARS-CoV as one of several viruses likely to cause epidemic in the future, which gives a possibility for another rise in this research field in the future since there are no current treatment or prophylactic vaccine to prevent or ameliorate the disease outbreak [6, 24].

United States produced the highest number of publications, this is not a surprise because United States have always played a prolific role in general scientific research from previous bibliometric researches [21, $23,25,26]$. This may also be due to the focus of the Center for Disease Control and Prevention (CDC) on potential coronavirus threats to humans than any other country $[27,28,29]$. Another reason is also the size, economic strength and stance of the country as the center of innovation; this can also be said about South Korea and China involvement in MERS-CoV and SARS-CoV research [27, 29, 30]. These two countries over the years are climbing ranks among the top research countries in the world [31, 32, 33]. Saudi Arabia, a middle-eastern country, comes out third among the top productive countries; may be due to the origination and outbreak of MERS-CoV from the middle east. These reasons can also be used to justify the high number of citations among these countries; with USA recording the highest followed by Saudi Arabia; with China, South Korea and Hong Kong also featuring among the top ten [21, 27, 29, 31, $32,34,35]$.

The Journal of Virology had the most published article in the field of MERS-CoV and SARS-CoV research, and this is not surprising since the journal specializes on viruses with a high IF of 4.324 [19].

Emerging Infectious Disease, PLOS One, Eurosurviellance and Mbio follow suit; from previous bibliometric studies, these journals are the top-ranking journals in microbial research and may be due to their high IF and the international presence they have in the scientific research field [19]. Zaki et al. was the first (2012) to report the outbreak of MERS-CoV in an article, making it the most cited publication in this research field. This is also due to the high impact factor (70.67) of the journal it was published in (New England Journal of Medicine) [21,23]. The second most cited publication also featured in the New England Journal of Medicine, reported by Assiri et al. in 2013 [12, 21]. This publication reported cases of MERS$\mathrm{CoV}$ in the middle eastern country. Other articles in the top ten cited publications also featured in high impact factor journals with global recognition; which may be the reason for its numerous citations [19]. Previous study showed that a higher IF of a journal result in a higher number of citations and that the most cited publications usually have high IF, which in turn make the IF go higher or stay high $[36,37]$.

The high number of authors, publications, international collaborations and citations showed the global impact of MERS-CoV and SARS-CoV in science and around the world. Research involves actions taken to produce and develop knowledge which are used to solve problems, develop new and better products and invent solution to global, continental, national, state and local crisis [38]. This bibliometric analysis in combination with previous bibliometric study proves that it is important to continue scientific researches to fight the current global problems; like the novel coronavirus (COVID-19 or SARS-CoV-2). 


\section{Conclusion}

This bibliometric study showed the trends of severe coronaviruses research from the outbreak of MERSCoV in 2012 till 2019, prior to the COVID-19 pandemic. It provides useful information on the trends of coronaviruses to tackle the novel COVID-19 outbreak. The analysis showed a rise in research followed by a decline after the containment of the outbreak in 2012. It also shows USA and Saudi Arabia as the top research countries on MERS-CoV and SARS-CoV; with majority of publications in this field are published by high-income countries. This study provides a useful reference for researchers and workers in the field of medicine, virology, epidemiology, microbiology, policy making and public health.

\section{Declarations}

\section{Acknowledgments}

Not applicable

\section{Funding}

No funding was received for writing this.

\section{Availability of data and materials}

Not applicable

\section{Ethics approval and consent to participate}

As a bibliometric analysis, there were no patients involved and only the use of secondary database, there was no institutional review board (IRB) approval and it was exempted.

\section{Competing interest}

The authors declare that there are no competing interests.

\section{References}

1. Fehr AR, Perlman S. Coronaviruses: An Overview of Their Replication and Pathogenesis. In: Maier H., Bickerton E., Britton P. (eds) Coronaviruses. Methods in Molecular Biology. 2015;1282. Humana Press, New York, NY

2. Khan JS, Mclntosh K. History and advances in coronavirus discovery. The Pedia Infect Dis Journal. 2005;24(11): s223-7.

3. Centers for Disease Control and Prevention. CDC SARS response timeline. Available from: https://www.cdc.gov/about/history/sars/timeline.htm [Accessed April 14, 2020]. 
4. National Institute of Health. COVID-19, MERS \& SARS. Available from: https://www.niaid.nih.gov/diseases-conditions/covid-19 [Accessed April 15, 2020].

5. Countries were COVID-19 spread. Available from https://www.worldometers.info/coronavirus/countries-where-coronavirus-has-spread/ [Accessed April 17, 2020].

6. World Health Organization. Public statement for collaboration on COVID-19 vaccine development. Available from: https://www.who.int/news-room/detail/13-04-2020-public-statement-forcollaboration-on-covid-19-vaccine-development [Accessed April 17, 2020]

7. Wang C, Horby PW, Hayden FG, Gao GF. A novel coronavirus outbreak of global health concern. The Lancet. 2020;385(10223)470-3.

8. Bonilla-Aldana DK, Quintero-Rada K, Montaya-Posada JP, Ramirez S, Paniz-Mondolfi AE, Rabaan A, Sah R, Rodriguez-Morales AJ. SARS-CoV, MERS-CoV and now the 2019-novel CoV: Have we investigated enough about coronaviruses? - A bibliometric analysis. Trav Med and Infect Dis. 2020; 33(101556).

9. Li F, Li W, Farzan M, Harrison SC. Structure of SARS Coronavirus Spike Receptor-Binding Domain Complexed with Receptor. Science. 2005; 309(1864-8).

10. Wong ACP, Li X, Lau SKP, Woo PCY. Global Epidemiology of Bat Coronaviruses. Viruses. 2019; 11(2)174.

11. Hui DS, Azhar El, Madani TA, Ntoumi F, Kock R, Dar O, Ippolito G, Mchugh TD, Memish ZA, Drosten C, Zumia A, Peterson E. The continuing 2019-nCoV epidemic threat of novel coronaviruses to global health-The latest 2019 novel coronavirus outbreak in Wuhan, China. Int Jour of Infect Dis. 2020; 91(264-6).

12. Assiri A, Al-Tawfiq JA, Al-Rabeeah AA, Al-Rabiah FA, Al-Hajjar S, Al-Barrak A, Flemban H, Al-Nassir WN, Balkhy $\mathrm{HH}$, Al-Hakeem RF, et al. Epidemiological, demographic, and clinical characteristics of 47 cases of Middle East respiratory syndrome coronavirus disease from Saudi Arabia: a descriptive study. Lancet Infect Dis. 2013;13(9):752-61.

13. AlRyalat SAS, Malkawi LW, Momani SM. Comparing Bibliometric Analysis Using PubMed, Scopus, and Web of Science Databases. J. Vis. Exp. 2019;(152): e58494-doi:10.3791/58494.

14. Scopus: Getting the most of published research. Available from: https://www.elsevier.com/solutions/scopus [Accessed April 17, 2020].

15. Scopus preview: Sources. Available from: https://www.scopus.com/sources [Accessed April 17, 2020].

16. De Groot SL, Raszewski RMS. Coverage of Google Scholar, Scopus, and Web of Science: A case study of the $h$-indexin nursing. Nurs Outlook. 2012;60(6): 391-400.

17. Zou, Y., Luo, Y., Zhang, J., Xia, N., Tan, G., \& Huang, C. Bibliometric analysis of oncolytic virus research, 2000 to 2018. Medicine.2006;98(35), e16817.

18. Ekundayo TC, Okoh Al. A global bibliometric analysis of Plesiomonas-related research (1990 2017). PLoS ONE. 2018;13(11), 1-17. 
19. SCImago, (n.d.). SJR - SCImago Journal \& Country Rank. Available from http://www.scimagojr.com [Accessed April 17, 2020].

20. Scopus Journal Info. Scopus Journal Info. Available from https://www.scopusjournals.info/ [Accessed April 16, 2020].

21. Zyoud, S. H. Global research trends of Middle East respiratory syndrome coronavirus: A bibliometric analysis. BMC Infect Dis. 2016;16(1), 1-7.

22. Aria, M. Cuccurullo, C. Bibliometrix: An R-tool for comprehensive science mapping analysis, Jour of Informetr. 2017;11(4), pp 959-75, Elsevier.

23. Zaki AM, van Boheemen S, Bestebroer TM, Osterhaus AD, Fouchier RA. Isolation of a novel coronavirus from a man with pneumonia in Saudi Arabia. N Engl J Med. 2012;367(19):1814-20.

24. World Health Organization. WHO MERS global summary and assessment of risk. Available from https://www.who.int/csr/disease/coronavirus_infections/risk-assessment-august-2018.pdf [Accessed April 16, 2020].

25. Hossain M. Current status of global research on novel coronavirus disease (covid-19): a bibliometric analysis and knowledge mapping. SSRN Elect Journ. 2020; DOI: 10.2139/ssrn.3547824.

26. Zielinska Best country for scientific research. Available from: https://www.thescientist.com/uncategorized/best-country-for-academic-research-45914 [Accessed April 16, 2020]

27. Williams H, Dunville R, Gerber S, Erdman D, Pesik N, Kuhar D, Mason K, et al. CDC's Early response to a novel viral disease, middle east respiratory syndrome Coronavirus (MERS-COV), September 2012May 2014. Public Health Reports. 2015; 130 (307-317).

28. Vouga M, Musso D, van Mieghem T, Baud D. CDC guidelines for pregnant women during the Zika virus outbreak. The Lanc. 2016;387(10021): 843-4.

29. Friedman AL, Shepard H. Exploring the knowledge, attitudes, beliefs, and communication preferences of the general public regarding HPV: findings from CDC focus group research and implications for practice. Healt Edu and Behav. 2007;34(3): 471-85.

30. Hsueh P, Chen P, Hsiao C, et al. Patient Data, Early SARS Epidemic, Taiwan. Emerg Infect Dis. 2004;10(3):489-93.

31. Kamalski J, L'Huillier. The rise of Asia: A research profile. Available from: https://www.elsevier.com/editors-update/story/publishing-trends/the-rise-of-asia-a-research-profile [Accessed April 17, 2020].

32. Chan J. Asia: The growing hub of scientific research. Available from: https://www.asianscientist.com/2011/04/features/asia-future-hub-scientific-research/ [Accessed April 17, 2020].

33. Five hubs of Asian science. Available from https://www.nature.com/articles/d41586-018-05504-3 [Accessed April 17, 2020].

34. Habibzadeh F. Scientific research in middle east. The Lanc. 2014;383: 1-2. 
35. Siddiqi A, Stoppani J, Anadon LD, Narayanamurti. Scientific wealth in Middle East and North Africa: productivity, indigeneity, and specialty in 1981-2013. PLOS One. 2016; https://doi.org/10.1371/journal.pone.0164500.

36. Finardi U. Correlation between Journal Impact Factor and Citation Performance: An experimental study. Jour of Informe. 2013;7(2): 357-70.

37. Torres-Salinas D, Rodríguez-Sánchez R, Robinson-García N, Fdez-Valdivia J, Garcia JA. Mapping citation patterns of book chapters in the Book Citation Index. Jour of Informe. 2013;7(2): 412-24.

38. Kumar R. Research and Development. Available from https://www.sciencedirect.com/topics/socialsciences/research-and-development [Accessed April 14, 2020].

\section{Tables}

Table 1: Overview of published scientific documents on MERS-CoV and SARS-CoV

\begin{tabular}{ll}
\hline Description & Findings \\
\hline Document type & Articles \\
No of documents & 1707 \\
Keywords plus (ID) & 8703 \\
Author's keywords & 2437 \\
Period & $2012-2019$ \\
Number of Citations & 39,094 \\
Average citations per documents & 22.80 \\
Authors & 7444 \\
Authors appearance & 14897 \\
Authors of single-authored documents & 87 \\
Authors of multi-authored documents & 7357 \\
Single-authored documents & 98 \\
Documents per author & 0.23 \\
Authors per document & 4.36 \\
Co-authors per documents & 8.73 \\
Annual percentage growth rate & 14.54 \\
Number of countries & 106 \\
Collaboration index & 4.57 \\
\hline
\end{tabular}

Table 2: The top ten countries/territories with scientific research on MERS-CoV and SARSCoV research at Scopus (up to December 31, 2019) 


\begin{tabular}{clcc}
\hline SCR & Countries/territories & $\begin{array}{c}\text { Total number of } \\
\text { publications (\%) }\end{array}$ & $\begin{array}{c}\text { Number (\%) of publications with } \\
\text { international collaboration }\end{array}$ \\
\hline $1^{\text {st }}$ & United States & $249(14.57)$ & $86(34.54)$ \\
$2^{\text {nd }}$ & South Korea & $186(10.89)$ & $27(14.52)$ \\
$3^{\text {rd }}$ & Saudi Arabia & $111(6.50)$ & $60(54.05)$ \\
$4^{\text {th }}$ & China & $91(5.33)$ & $25(51.02)$ \\
$5^{\text {th }}$ & Germany & $49(2.87)$ & $23(56.09)$ \\
$6^{\text {th }}$ & Hong Kong & $41(2.40)$ & $15(41.67)$ \\
$7^{\text {th }}$ & United Kingdom & $36(2.11)$ & $17(50.00)$ \\
$8^{\text {th }}$ & Japan & $34(1.99)$ & $6(23.08)$ \\
$9^{\text {th }}$ & Taiwan & $26(1.52)$ & $19(79.17)$ \\
$10^{\text {th }}$ & Netherlands & $24(1.41)$ & \\
\hline
\end{tabular}

$S C R$ standard competition rankings

Table 3: The 10 most published journals

\begin{tabular}{clcc}
\hline SCR $^{\text {a }}$ & Journal & $\begin{array}{l}\text { Frequency } \\
(\%)\end{array}$ & IF $^{\mathbf{b}}$ \\
\hline $1^{\text {st }}$ & Journal of Virology & $133(7.79)$ & 4.324 \\
$2^{\text {nd }}$ & Emerging Infectious Diseases & $85(4.69)$ & 7.422 \\
$3^{\text {rd }}$ & PLOS One & $60(3.51)$ & 2.776 \\
$4^{\text {th }}$ & Eurosurveillance & $36(2.11)$ & 7.150 \\
$5^{\text {th }}$ & MBio & $34(1.99)$ & 6.747 \\
$6^{\text {th }}$ & Scientific Reports & $32(1.88)$ & 4.011 \\
$7^{\text {th }}$ & Viruses & $29(1.69)$ & 3.811 \\
$8^{\text {th }}$ & Proceedings of the National Academy of Sciences of the United & & \\
& States of America & $26(1.52)$ & 9.580 \\
$9^{\text {th }}$ & International Journal of Infectious Diseases & $25(1.47)$ & 3.538 \\
$10^{\text {th }}$ & Journal of Infection and Public Health & $25(1.47)$ & 2.487 \\
\hline
\end{tabular}

SCR standard competition ranking, IF impact factor. ${ }^{a}$ Equal journals have the same number of ranking. ${ }^{\mathrm{b}}$ The impact factor was reported according to the SCImago Journal \& Country Rank (2020)

Table 4: The top ten cited publications 


\begin{tabular}{|c|c|c|c|c|c|c|}
\hline $\mathrm{SCR}^{\mathrm{a}}$ & Authors & Source title & $\begin{array}{c}\text { Year of } \\
\text { publication }\end{array}$ & $\mathrm{IF}^{\mathrm{b}}$ & TC & TC/Year \\
\hline $1^{\text {st }}$ & Zaki et al & $\begin{array}{c}\text { New England Journal of } \\
\text { Medicine }\end{array}$ & 2012 & 70.670 & 1400 & 155.60 \\
\hline $2^{\text {nd }}$ & Assiri et al & $\begin{array}{c}\text { New England Journal of } \\
\text { Medicine }\end{array}$ & 2013 & 70.670 & 587 & 73.40 \\
\hline $3^{\text {rd }}$ & $\begin{array}{l}\text { Agarwala et } \\
\text { al }\end{array}$ & Nucleic Acid Research & 2016 & 11.147 & 487 & 97.40 \\
\hline $4^{\text {th }}$ & Assiri et al & $\begin{array}{c}\text { The Lancet Infectious } \\
\text { Diseases }\end{array}$ & 2013 & 27.516 & 391 & 48.90 \\
\hline $5^{\text {th }}$ & $\begin{array}{l}\text { Reusken et } \\
\text { al }\end{array}$ & $\begin{array}{c}\text { The Lancet Infectious } \\
\text { Diseases }\end{array}$ & 2013 & 27.516 & 374 & 46.80 \\
\hline $6^{\text {th }}$ & $\begin{array}{l}\text { De Groot et } \\
\text { al }\end{array}$ & Journal of Virology & 2013 & 4.324 & 361 & 45.10 \\
\hline $7^{\text {th }}$ & Ge et al & Nature & 2013 & 43.070 & 322 & 40.20 \\
\hline $8^{\text {th }}$ & $\begin{array}{l}\text { Memish et } \\
\text { al }\end{array}$ & $\begin{array}{c}\text { Emerging Infectious } \\
\text { Diseases }\end{array}$ & 2013 & 7.422 & 307 & 38.40 \\
\hline $9^{\text {th }}$ & $\begin{array}{l}\text { Haagmans } \\
\text { et al }\end{array}$ & $\begin{array}{c}\text { The Lancet Infectious } \\
\text { Diseases }\end{array}$ & 2014 & 27.516 & 304 & 43.40 \\
\hline $10^{\text {th }}$ & Azhar et al & $\begin{array}{c}\text { New England Journal of } \\
\text { Medicine }\end{array}$ & 2014 & 70.670 & 299 & 42.70 \\
\hline
\end{tabular}

SCR standard competition ranking, IF impact factor, $T C$ total citations. ${ }^{\text {a }}$ Same journals have the same number of ranking ${ }^{b}$ The impact factor was provided according to the SCImago Journal \& Country Rank (2020).

Table 5: Total citations per country 


\begin{tabular}{llll}
\hline SCR & Country & Total Citations & Average Article Citations \\
\hline $1^{\text {st }}$ & USA & 7824 & 31.42 \\
$2^{\text {nd }}$ & Saudi Arabia & 4701 & 42.35 \\
$3^{\text {rd }}$ & Netherlands & 3411 & 142.12 \\
$4^{\text {th }}$ & China & 2294 & 25.21 \\
$5^{\text {th }}$ & Germany & 1951 & 39.82 \\
$6^{\text {th }}$ & South Korea & 1706 & 9.17 \\
$7^{\text {th }}$ & Hong Kong & 1687 & 41.15 \\
$8^{\text {th }}$ & United Kingdom & 896 & 24.89 \\
$9^{\text {th }}$ & France & 796 & 36.18 \\
$1^{\text {th }}$ & Japan & 550 & 16.18 \\
\hline
\end{tabular}

SCR standard competition ranking, IF impact factor. ${ }^{a}$ Equal journals have the same number of ranking. ${ }^{\mathrm{b}}$ The impact factor was reported according to the SCImago Journal \& Country Rank (2020).

\section{Figures}

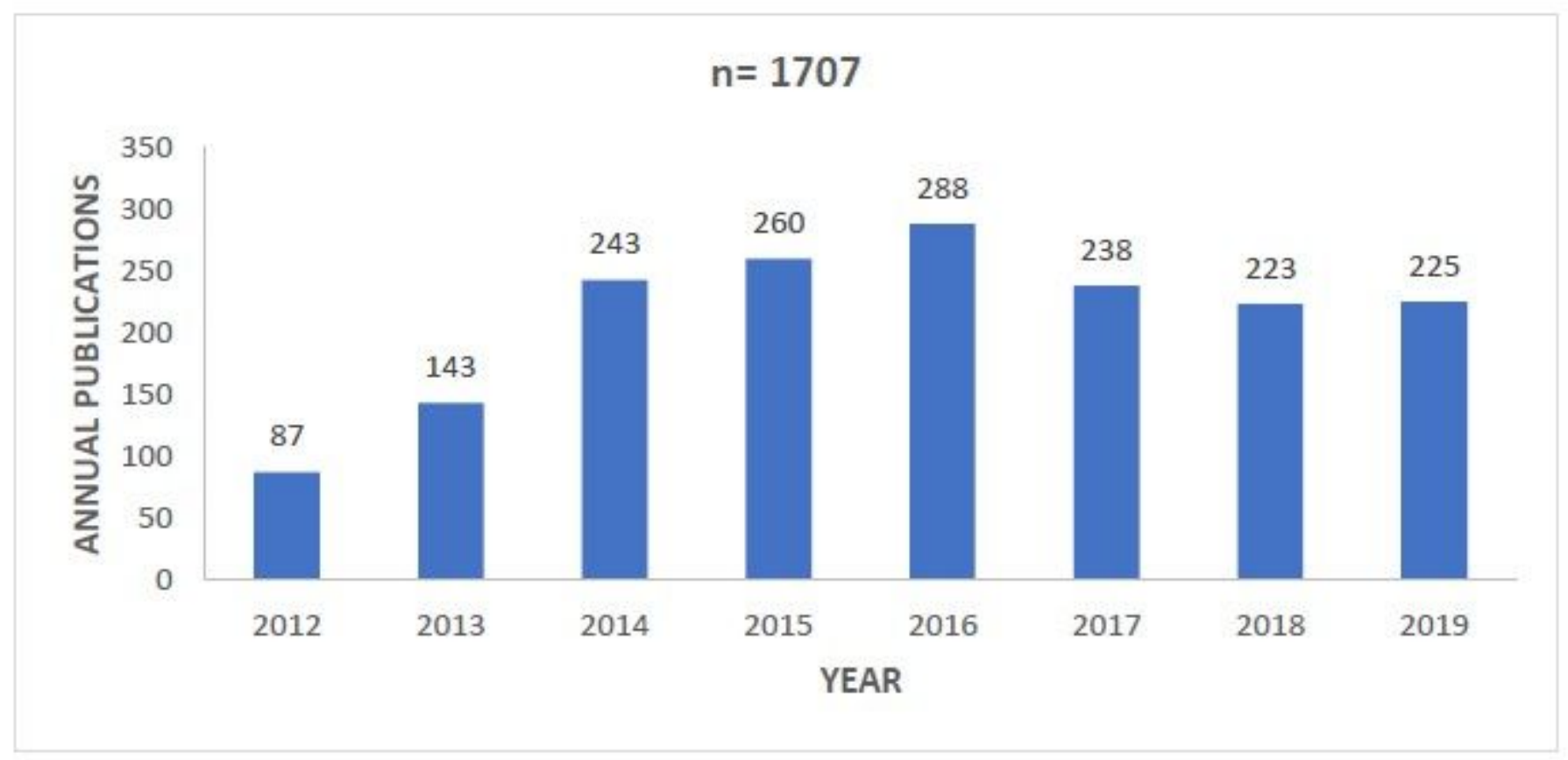

\section{Figure 1}

Distribution of yearly publications on SARS-CoV and MERS-CoV from 2012 to 2019 


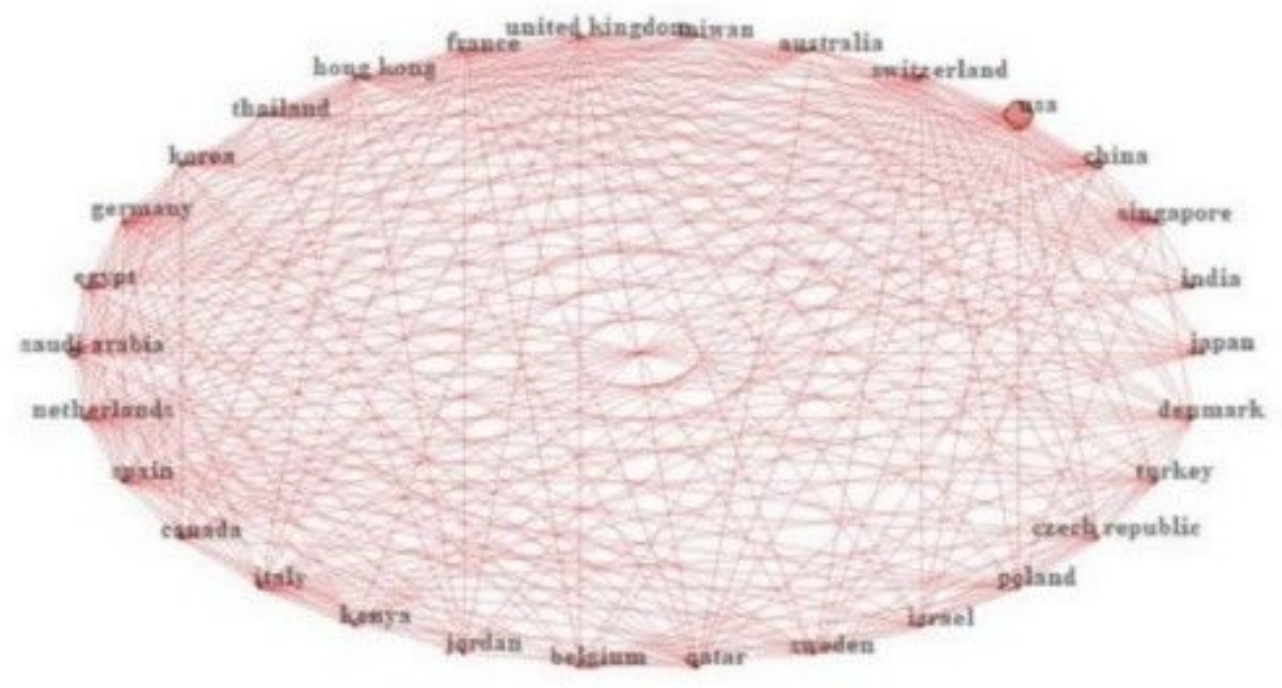

Figure 2

Countries/territories collaborations focusing on MERS-CoV and SARS-CoV research

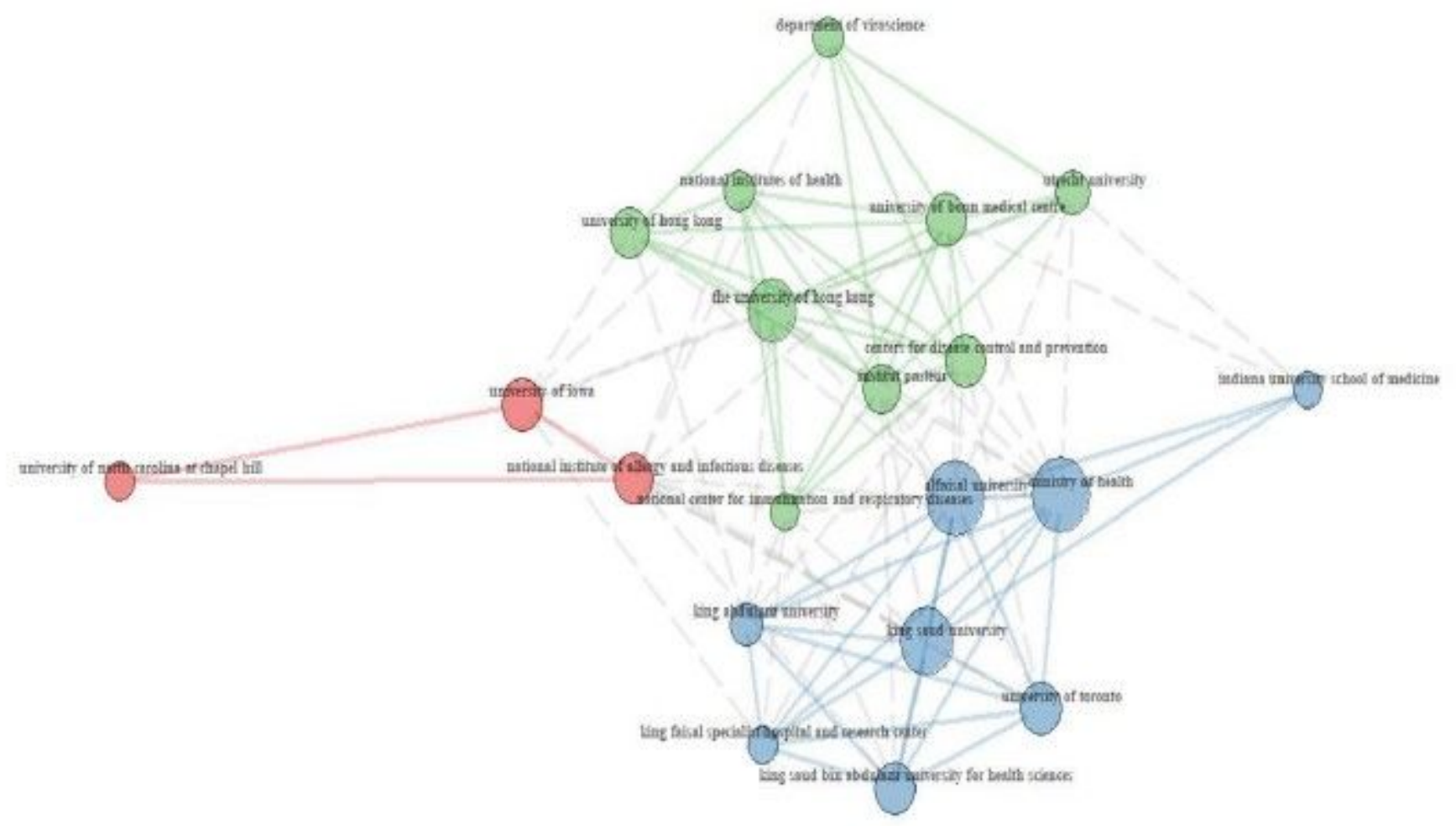

\section{Figure 3}

The top 20 highly productive and influential institutions in SARS-CoV and MERS-CoV research field. 


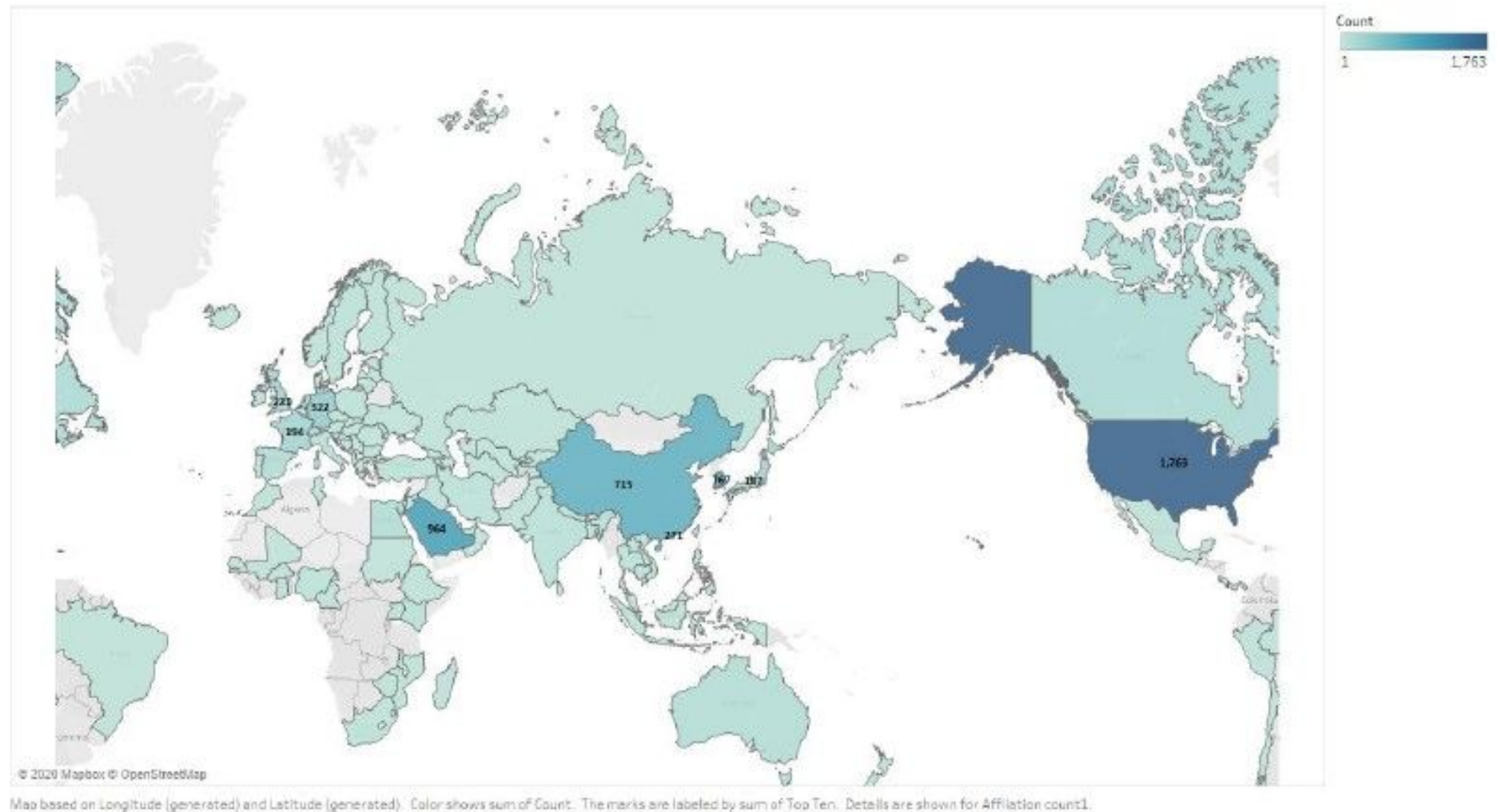

\section{Figure 4}

The top ten countries with the highest number of authors. Note: The designations employed and the presentation of the material on this map do not imply the expression of any opinion whatsoever on the part of Research Square concerning the legal status of any country, territory, city or area or of its authorities, or concerning the delimitation of its frontiers or boundaries. This map has been provided by the authors. 